\title{
Clinical and Demographic Characteristics of the Patients with Diffuse Hyperpigmentation
}

\author{
[1] Ayşe Akbaş, 마 Fadime Kılınç
}

'Department of Dermatology Ankara City Hospital, Ankara, Turkey

Submitted: 08.03.2019 Accepted: 27.12.2019

Correspondence: Ayşe Akbaş, Ankara Şehir Hastanesi, Dermatoloji Kliniği, Ankara, Turkey E-mail: ayseakbas62@gmail.com

articis

Keywords: Amyloidosis; epidemiology; erythema discromicum perstans; hyperpigmentation.

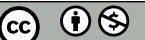

This work is licensed under a Creative Common Attribution-NonCommercial 4.0 International License.

\begin{abstract}
Objective: Hyperpigmentation is a condition characterized by the accumulation of pigment in the epidermis and dermis. Many dermatological diseases, such as primary cutaneous amyloidosis (PCA), postinflammatory hyperpigmentation (PIH), erythema discromicum perstans (EDP), notalgia paresthetica (NP), drug reaction (DR), may lead to acquired hyperpigmentation on the skin. The aim of this study is to investigate etiologic factors, clinical and demographic features, laboratory findings and treatment options in patients with generalized hyperpigmentation.
\end{abstract}

Methods: Forty four patients who presented to our outpatient clinic with complaints of hyperpigmentation were evaluated retrospectively. Patients were examined in terms of age, duration and localization of lesions, accompanying symptoms or diseases, laboratory findings and treatment options.

Results: When pigmentation-causing diseases are listed; PCA was detected in $50 \%$ of the cases. Of these, $72.7 \%(n=16)$ were macular amyloidosis, $22.7 \%(n=5)$ were lichen amyloidosis, and $4.6 \%(n=I)$ were biphasic amyloidosis. Others were $29.5 \%(n=13) \mathrm{PIH}, 13.6 \%(n=6)$ EDP, $4.6 \%(n=2)$ NP, $2.3 \%(n=1)$ DR. The ages of the patients were generally between 20-69 years. The average age was mean 47.8 years ( 48.8 for females and 45.0 for males). The duration of pigmentation ranged from 3 months to 20 years (mean 6.8 years). $75 \%(n=33)$ of the patients had itching. About half of the lesions were located on the back. Half of the patients had a concomitant disease. As treatment options, 9 patients were treated with phototherapy, 9 with isotretinoin, 12 with depigmentation, and one with pregabalin and topical steroids.

Conclusion: Knowing the conditions that cause hyperpigmentation facilitates the diagnosis of the disease. In this study, PCA was detected in half of the patients with clinically considered hyperpigmentation. Therefore, the diagnosis of PCA should be considered first in patients with pruritic and diffuse pigmentation.

\section{INTRODUCTION}

The presence of hyperpigmentation on the skin is a common complaint of the patients who appeal to dermatology outpatient clinics. Hyperpigmentation is a situation characterised with accumulation of pigment in the epidermis and dermis. Many dermatological diseases such as PCA, PIH, EDP, NP, DR can cause acquired hyperpigmentation in the body. PCA is the deposition of amyloid in the skin without systemic involvement. There are various types as macular, lichenoid, biphasic and nodular in which macular and lichenoid types exist together. ${ }^{[1-4]} \mathrm{PIH}$ is an increase of acquired melanin in the epidermis and/or dermis due to many reasons such as inflammatory dermatosis, allergic reactions, papulosquamous diseases, drug reactions, phototoxic reactions, trauma and physical agents. ${ }^{[5-8]}$ EDP; also known as ashy dermatosis, is an acquired dermatosis with an unknown etiology characterized by common gray-blue macules. ${ }^{[9,10]} \mathrm{NP}$ is a clinical condition with focal, severe itching, neuropathic pain and pigmentation on the dorsal vertebra and scapula with attacks. ${ }^{[1]} \mathrm{DR}$ is characterized with the drug-induced pigmentation on the skin and mucous appendages. ${ }^{[12]}$ Establishing differential diagnosis of hyperpigmentation is important in terms of diagnosis and treatment plan.

In this study, it is aimed to present the etiological reasons, demographic characteristics, clinical and laboratory findings, treatment options that patients appeal with diffuse hyperpigmentation by comparing them with the literature data.

\section{MATERIALS AND METHODS}

In this study, 44 patients evaluated retrospectively who applied to our Dermatology outpatient clinic with the 
complaint of diffuse hyperpigmentation between 2013 and 2018. Diseases that may cause pigmentation were investigated on these patients. For the diagnosis, in addition to the clinical examination, histopathological examination was done by taking biopsy from all patients. The PCA was diagnosed by presence of amyloid, hematoxylin-eosin (H\&E) and Congo red stain. Patients with pictures had a consent form. Patients were reviewed in terms of age, duration of lesion, localization, concominant symptoms or diseases, laboratory findings and treatment options.

The patients were grouped according to their ages as 2030a, 3I-40a, 4I-50a, 5I-60a, 6I-70a.

Durations of disease were grouped as 0-6 months, 7 months-12 months, I year-5-years, 6-10 years, and more than 10 years. The presence of itching was particularly noted.

Statistical analysis of the data of the study was performed by using the SPSS 21.0 package program. Continuous variables were shown as means, and categorical variables were presented as percentages.

\section{RESULTS}

When diseases causing pigmentation were listed; PCA was detected as $50 \%$ of the cases. $72.7 \%(n=16)$ of it was macular amyloidosis, $22.7 \%(n=5)$ was lichen amyloidosis, $4.6 \%$ $(n=I)$ was biphasic amyloidosis. The others were detected as $29.5 \%(n=13) \mathrm{PIH}, 13.6 \%(n=6)$ EDP, $4.6 \%(n=2)$ NP, and $2.3 \%(n=I)$ DR (Figs. I, 2).

$75 \%$ of the patients were female $(n=33)$ and $25 \%(n=I I)$ were male. The female/male ratio was 3: I. The rates of diseases that cause pigmentation and the distribution by gender are shown in Table $\mathrm{I}$.

The ages of the patients with diffuse hyperpigmentation that we followed up in our outpatient clinic were generally between the ages of 20-69 (mean 47.8), 48.8 for women and 45.09 for men. Hyperpigmentation diseases by age groups are shown in Table 2 . The pigmentation period varied from 3 months to 20 years (mean 6.8 years) (Table 3 ). $75 \%(n=33)$ of the patients had itching complaints. While all patients with NP and DR were itchy, in lichenoid and macular amylodosis itching was $90.9 \%$, PIH was $58.3 \%$ and EDP was $50 \%$. When the hyperpigmentation in the cases was evaluated in terms of localization, it was observed that the lesions were mostly located in the body. It was mostly on the back in $45.4 \%$ (20 cases). 2 cases (4.6\%) were determined in the legs, one case $(2.3 \%)$ in the arms, 13 cases $(29.5 \%)$ in more than one localization, and 8 cases (18.2\%) generalized hyperpigmentation.

Hyperpigmentation locations of the cases are shown in Table 4.

Two cases had a severe sunburn history. Family history was not determined in any patient.

Complete blood count, routine biochemistry tests, thyroid function tests, Antinuclear antibody (ANA) tests, Anti-dsDNA tests were performed on the patients. ANA positivity was observed in one patient. Half of the patients had a concomitant diseases. More than one disease was determined

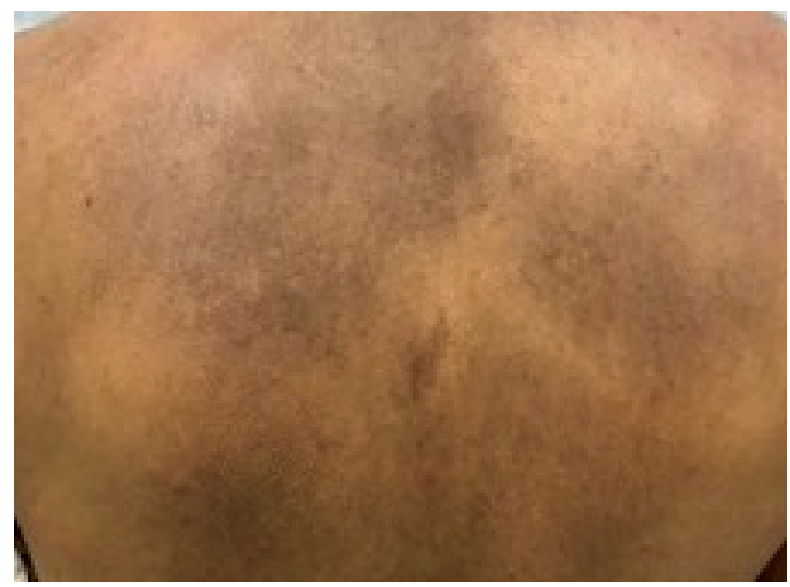

Figure 1. Macular amyloidosis in the back.

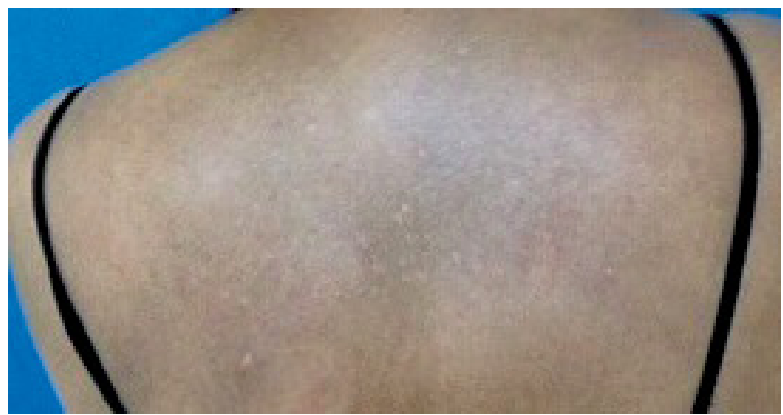

Figure 2. Postinflammatory hyperpigmentation in the back.

Table I. The rates of pigmentation-causing diseases and their distribution by gender

\begin{tabular}{|c|c|c|c|c|c|c|c|c|c|}
\hline Gender & MA & LA & BFA & Total amyloidosis & PIH & EDP & NP & DR & Total \\
\hline Male & 5 & I & I & 7 & 2 & I & - & I & 11 \\
\hline$\%$ & & & & & & & & & 25 \\
\hline The average age & & & & & & & & & 47.8 \\
\hline Female & II & 4 & - & 15 & II & 5 & 2 & - & 33 \\
\hline$\%$ & & & & & & & & & 75 \\
\hline The average age & & & & & & & & & 48.8 \\
\hline Total cases, n (\%) & $16(36.4)$ & $5(11.3)$ & I (2.3) & $22(50)$ & $13(29.5)$ & $6(13.6)$ & $2(4.6)$ & I (2.3) & $44(100)$ \\
\hline
\end{tabular}

MA: Macular amyloidosis; LA: Lichenoid amyloidosis; BFA: Biphasic amyloidosis; PIH: Postinflammatory hyperpigmentation; EDP: Erythema dyschromicum perstans; NP: Notalgia paresthetics; DR: Drug reaction. 
Table 2. Hyperpigmentation diseases by age groups

\begin{tabular}{|c|c|c|c|c|c|c|c|}
\hline Disease groups & Number of cases & $20-30 y$ & $31-40 y$ & $4 I-50 y$ & $51-60 y$ & $61-70 y$ & The average age \\
\hline MA & 16 & I & 2 & 5 & 4 & 4 & 50.75 \\
\hline LA & 5 & - & I & 2 & 2 & - & 47.2 \\
\hline BFA & 1 & - & 1 & - & - & - & 37 \\
\hline $\mathrm{PIH}$ & 13 & I & - & 3 & 5 & 4 & 52.46 \\
\hline EDP & 6 & 2 & 1 & 2 & I & - & 37.6 \\
\hline NP & 2 & - & - & 2 & - & - & 44 \\
\hline DR & I & I & - & & - & - & 26 \\
\hline Total & 44 & 5 & 5 & 14 & 12 & 8 & 48.7 \\
\hline
\end{tabular}

MA: Macular amyloidosis; LA: Lichenoid amyloidosis; BFA: Biphasic amyloidosis; PIH: Postinflammatory hyperpigmentation; EDP: Erythema dyschromicum perstans; NP: Notalgia paresthetics; DR: Drug reaction; y: years.

Table 3. Duration of the disease

\begin{tabular}{lccccccc}
\hline Disease groups & $\begin{array}{c}\text { Number of } \\
\text { cases }\end{array}$ & $\begin{array}{c}\mathbf{0 - 6} \\
\text { months }\end{array}$ & $\begin{array}{c}\mathbf{7 - 1 2} \\
\text { months }\end{array}$ & $\begin{array}{c}\text { I-5 } \\
\text { years }\end{array}$ & $\begin{array}{c}\mathbf{6 - 1 0} \\
\text { years }\end{array}$ & $\begin{array}{c}\text { More than } \\
\text { 10 years }\end{array}$ & $\begin{array}{c}\text { Average duration } \\
\text { of illness }\end{array}$ \\
\hline MA & 16 & - & 1 & 6 & 2 & 7 & 10.6 years \\
LA & 5 & 1 & - & - & - & 4 & 11.2 years \\
BFA & 1 & - & 1 & - & - & - & 1.5 years \\
PIH & 13 & 2 & 4 & 1 & 3 & 2 & 5.76 years \\
EDP & 6 & - & 1 & 2 & 1 & -6.1 years \\
NP & 2 & - & - & 1 & - & -1 & 7 years \\
DR & 1 & - & - & 1 & - & - & 6 months \\
Total & 44 & 3 & 7 & 11 & 6 & 17 & 6.8 years \\
\hline
\end{tabular}

MA: Macular amyloidosis; LA: Lichenoid amyloidosis; BFA: Biphasic amyloidosis; PID: Postinflammatory hyperpigmentation; EDP: Erythema dyschromicum perstans; NP: Notalgia paresthetics; DR: Drug reaction.

Table 4. Pigmentation localization

\begin{tabular}{|c|c|c|c|c|c|c|c|c|c|}
\hline Localization & & MA & LA & BFA & Total amyloidosis & PIH & EDP & NP & DR \\
\hline Arms, n (\%) & I (2.3) & - & I & & 1 & - & - & - & - \\
\hline Legs, n (\%) & $2(4.6)$ & - & 2 & & 2 & - & - & - & - \\
\hline Trunk, n (\%) & $20(45.4)$ & 9 & I & & 10 & 6 & 2 & 2 & - \\
\hline Multiple locations, n (\%) & I3 (29.5) & 6 & 1 & & 7 & 4 & 1 & - & I \\
\hline Diffuse, n (\%) & $8(18.2)$ & I & - & I & 2 & 3 & 3 & - & - \\
\hline Total & 44 & 16 & 5 & I & 22 & 13 & 6 & 2 & 1 \\
\hline
\end{tabular}

MA: Macular amyloidosis; LA: Lichenoid amyloidosis; BFA: Biphasic amyloidosis; PID: Postinflammatory hyperpigmentation; EDP: Erythema dyschromicum perstans; NP: Notalgia paresthetics; DR: Drug reaction.

in 14 cases (31.8\%). Concomitant diseases in 6 patients; thyroid pathology in four patients; asthma, iron deficiency anemia, hypertension $(\mathrm{HT})$ in three patients; diabetes mellitus (DM), vitamin BI2 deficiency anemia in two patients; vitamin $D$ deficiency and fibromyalgia in one patient; allergic rhinitis, coronary artery disease, varicose veins, migraine and depression were determined. In addition, skin diseases such as psoriasis, vitiligo, chronic urticaria, perforating collagenesis and atopic dermatitis were detected in one patient.

As treatment options, 8 cases were given darbant B, I case was given PUVA, 9 cases were given isotretinoin, 12 cases were given depigmentation therapy, I case was given each Pregabalin and topical steroid. Thirteen patients did not receive treatment.
Presence of itching according to diseases, concomitant diseases and treatments given are shown in Table 5.

\section{DISCUSSION}

Knowing the conditions that cause hyperpigmentation facilitates the diagnosis of the disease. In this study, hyperpigmentation diseases were investigated. It is necessary to make a differential diagnosis of hyperpigmentation in terms of diagnosis and treatment plan. Generally, hyperpigmentation is more common in middle-aged women. Hormonal and cosmetic reasons may be effective. PCA has been detected in half of the patients who are clinically suspected of having hyperpigmentation. Therefore, in patients present- 
ing with itchy and extensive pigmentation, the diagnosis of PCA should be considered first and the diagnosis should be confirmed by histopathology. Since there is a considerable number of cases of $\mathrm{PIH}$, a good history should be taken and treatment should be applied according to the cause.

\section{DISCUSSION}

In the literature, many epidemiological studies have been made on patients who appeal with diffuse hyperpigmentation complaints, but these were evaluated as disease-specific. There are not many studies that hyperpigmentation has been reviewed collectively. In this study, 44 patients who applied with diffuse hyperpigmentation complaint were evaluated retrospectively. The clinical and demographic characteristics of the patients, diseases that cause pigmentation, localization, laboratory findings and concominant diseases were evaluated and compared with the literature datas.
PCA occurs all over the world. However, it is more common in South America, Ecuador, and in Southeast Asia as China, Malaysia, Indonesia, India and on people with skin type 4 and higher. ${ }^{[4,7,13]}$ Therefore, more studies on amyloidosis have been reported from these countries.

The incidence of PCA and PIH is low in people with low skin type living in places like Europe and North America. PCA is not seen frequently in our country. ${ }^{[4,9,14-16]} \mathrm{Pa}$ tients with diffuse hyperpigmentation have high ratio of PCA. ${ }^{[7]}$ In various studies, histologically $46.7-50 \%$ of amyloid was found in patients with pigmentation. ${ }^{[17-19]}$ Also in this study, it was stated that H\&E and Congo red stain were used to detect amyloid as in others. ${ }^{[2]}$ In our study, PCA was detected in half of the cases. $72.7 \%(n=16)$ of PCA cases were macular amyloidosis (MA), $22.7 \%(n=5)$ were lichen amyloidosis (LA), 4.6\% $(n=1)$ were biphasic amyloidosis (BFA).

Amyloidosis types have been reported in different ratios in the various studies made about PCA. ${ }^{[20]}$

Table 5. Presence of itching, accompanying diseases, treatments given in cases with pigmentation

\begin{tabular}{|c|c|c|c|}
\hline & Presence of itching \% & Concomitant diseases & Treatment \\
\hline Amyloidosis, & 20 cases & 2-VBD & 7-Isotretinoin \\
\hline 22 cases & & 3-IDA & 8-Narrowband B treatment \\
\hline \multirow[t]{8}{*}{$50 \%$} & $90.9 \%$ & 2-Thyroid pathology & I-Depigmentation treatment \\
\hline & & I-Migraine & I-PUVA \\
\hline & & I-Perforan collagenesis & \\
\hline & & I-Psoriasis & \\
\hline & & I-Vitiligo & \\
\hline & & 3-Asthma & \\
\hline & & I-Allergic rhinitis & \\
\hline & & I-Atopic dermatitis & \\
\hline $\mathrm{PIH}$ & 7 cases & I-Fibromyalgia & Depigmentation treatment \\
\hline 13 cases & $53.8 \%$ & 3 Thyroid pathology & \\
\hline \multirow[t]{6}{*}{$29.5 \%$} & & 2-DM & \\
\hline & & $4-\mathrm{HT}$ & \\
\hline & & I-Varicose veins & \\
\hline & & I-VDD & \\
\hline & & I-Asthma & \\
\hline & & I-Chronic urticaria & \\
\hline EDP & 3 cases & I-Fibromyalgia & 2-Isotretinoin \\
\hline 6 cases & $50 \%$ & I-Thyroid pathology & I-Narrowband B treatment \\
\hline \multirow[t]{4}{*}{$13.6 \%$} & & I-DM & I-Depigmentation treatment \\
\hline & & I-CAD & \\
\hline & & I-VDD & \\
\hline & & I-Depression & \\
\hline NP & 2 cases & I-VBD & Pregabalin \\
\hline 2 cases & $100 \%$ & I-IDA & \\
\hline $4.6 \%$ & & I-VDD & \\
\hline DR & I & - & - \\
\hline $2.3 \%$ & $100 \%$ & & \\
\hline \multirow[t]{2}{*}{ Total } & 33 cases & 39 Concomitant diseases in 22 cases & \\
\hline & $75 \%$ & $31.8 \%$ ( 14 cases) more than one disease & \\
\hline
\end{tabular}


Salim et al. ${ }^{[2]]}$ reported that all cases in their study were lichenoid type, while Wang et al. ${ }^{[22]}$ found the lichenoid type to be $67 \%$ in their 26 -year comprehensive study in China. We detected the lichenoid type at a rate of $22.72 \%$. MA was detected as $72 \%$, similar to some studies in India.

Biphasic amyloidosis, in which the two types coexist, was at a lower rate $(4.6 \%)$ in our study compared to the literature. These differences can be caused by genetic and geographic factors. Histopathologically, $29.5 \%$ of other biopsies taken with the prediagnosis of hyperpigmentation were $\mathrm{PIH}, 13.6 \%(n=6) \mathrm{EDP}, 4,6 \%(n=2) \mathrm{NP}$, and one case $(2.3 \%)$ was deteced that it was interpreted as DR.

In our study, the age of the patients with pigmentation was between 20 and 69 and the mean age was 47.8 .

The researchers found the average age of cases with amyloidosis between 28-48.35. ${ }^{[13,17,19,23-30]}$ In this study, the mean age of the patients with PCA was 49.3 years.

In other studies, MA was determined more in younger ages such as $2 \mathrm{I}-40$, while LA was found more between the ages of $4 I-50 . .^{[1,24]}$ In this study, it was determined that both LA and MA appeared at a later age, as in another study made in our country. ${ }^{[3]]}$

$\mathrm{PIH}$ can be seen at every age. ${ }^{[16]}$ In our study, it was found that there were more between the ages of $41-70$ and the mean age was 52.4 years.

EDP is more common in young adults at the ages of 20 and $30{ }^{[9,10,32]}$ In some studies, EDP has been reported to be higher between the ages of 20-50 and the mean age as 33.9 and 37.6 years. ${ }^{[10,33]}$ In our study, the mean of EDP was similar to these (37.6\%). Its occurrence at an older age may be due to genetic factors and delay in diagnosis.

$\mathrm{NP}$ is more common between the ages of 50-60. ${ }^{[1]}$ Both cases in this study were female, the average of age was 44.

The drug reaction was just a case.

PCA is generally seen equally in young adults and in both genders, while male superiority was found $63-86 \%$ in some studies, ${ }^{[13,34,35]}$ but some studies reported female superiority. ${ }^{[1,17,18,23,24,28,30,31]}$ We also saw the $M / F$ ratio of $I: 3$ and more in female. The reason why PCA is seen more in female may be due to the high number of applications due to hormonal or cosmetic concerns. ${ }^{[26,28,30]}$

$\mathrm{PIH}$ can be seen in both genders. ${ }^{[6,7]}$ In our study, it was higher in female.

EDP is also more common in female. ${ }^{[9,10]}$ In our study, female superiority was also in question.

Female dominance is also at the forefront in NP. ${ }^{[11,30]}$

In our study, the average duration for all pigmentations was determined to be 6.8 years.

Studies have shown that the duration of PCA disease ranges from 3 months to 40 years. ${ }^{[1,21,23,24,29]}$ In our study, this period was found to be between I year and 20 years, the average duration was 10.6 years in macular type and II.2 years in lichenoid type. These changes may be due to the patients being followed up in different places, not being diagnosed or missed.

Lesions in PIH usually regress in a few months. Sometimes dermal ones can last longer, even be permanent. ${ }^{[6]}$ In this study, the average duration of PIH was found to be 5.76 years.

While the diagnosis time of EDP was found between 6 months and 2 years in studies made in Korea, in this study the average diagnosis time was found to be 6 years. ${ }^{[10,33]}$

The duration in NP has been reported as 21 months-3 years. ${ }^{[1,36]}$ In this study, it was determined to be 7 years on average.

Drug-induced hyperpigmentation progresses slowly and can occur over a long period of time. ${ }^{[12]}$ There was only one case in this study and he had a complaint for 6 months. However, the causative drug could not be identified. Patients should be questioned in detail in terms of drug history.

In this study, hyperpigmentation was generally located in the body with a rate of $45.4 \%$. The rate of $29.5 \%$ had more than one site and the rate of $18.2 \%$ had more common involvement.

MA may be most common in the back, interscapular region and less commonly in the anterior body, chest, arms, gluteal area, and thighs and rarely in the whole body. ${ }^{[3,9,19]}$ Mehrotra et al. ${ }^{[23]}$ reported that amyloidosis is located in more than one place in all patients and is most common in the arms, is located in the back in only half of the cases. Similarly, $56.25 \%$ of the patients with macular amyloidosis were localized only on the back in this study. Studies have reported that lichen amyloidosis is mostly located on the outer surface of the extremities such as the pretibial region, on the back, and to a lesser extent in te other body areas such as the ankles, thighs, abdominal area, anterior chest wall, sacral region and auricular concha. . $^{[2,3,13,19,21,23,29,34]}$ In this study, lichenoid amyloidosiss was localized to the legs and arms and was similar to other studies in the literatüre.

The biphasic type is mostly located on the extensor faces of the legs and arms. ${ }^{[2]}$ The only case in this study was similar to the others in terms of location.

Some authors reported that more than one site involvement occurred in more than half of the cases with amyloidosis. ${ }^{[18,26]}$ In this study, the multi site involvement rate of amyloidosis was $40.9 \%$.

$\mathrm{PIH}$ is geneally characterized by limited lesions and can ocur anywhere. However, depending on the stimulus, it may be widely located in the body as in this study. ${ }^{[15,16]}$ Lesions in EDP may be mostly on the body, sometimes on the face, neck and extremities. ${ }^{[14]}$ Body involvement has been reported at a rate of $66-69 \%{ }^{[10,33]}$ Body involvements and widespread were also found in this study.

Locations of hyperpigmentation according to diseases are shown in Table 4. 
Although the etiology of PCA is not fully known, various factors such as atopy, itching friction, use of cosmetics, and sun exposure may trigger the event. ${ }^{[6,7]}$ Some studies found atopy at a rate of 10.7-69 \%. ${ }^{[17,18]}$ Jayabhanu et al. ${ }^{[29]}$ found asthma $14.7 \%$. In this study, the detection of asthma in 4 cases (13.6\%) and allergic rhinitis and atopic dermatitis in one case may show the relationship between atopic body and amyloidosis. However, the low rate of atopy may be due to the low number of patients. We think that as the number of patients increases, the rate of relationship between atopy may increase. Eswarmoorthy et al. ${ }^{[17]}$ however, they could not establish this relationship with amyloidosis.

As in some previous studies, no relationship was found between cosmetic agents and amyloidosis in this study. ${ }^{[26]}$

Localized trauma and itching are the most common causes of PCA. ${ }^{[37]}$ It is thought that hyperpigmentation develops due to a continuous stimulus such as rubbing or scratching activities and increases melanin synthesis or the proliferation of melanocytes. ${ }^{[37]}$ In recent years, increases in PCA cases has been detected in some countries with mechanical friction with objects such as synthetic towels and nylon brushes. ${ }^{[28,37]}$ Scrubbing, which is common in our country, can cause PCA and hyperpigmentation.

Itching may begin before the lesions appear, and it is considered as a process of cutaneous amyloidosis. ${ }^{[1-3]}$ In various studies itching was detected at the rate of (34-90\%). [13,19,21,23-26,29,30]

In our study, $75 \%$ of all patients had itching. It was found that pruritus was mostly seen in lichenoid and macular amylodosis.

Itching was present in both patients with NP and in half of the patients in EDP.

In some studies, exposuring to sunligt was detected at the rate of $33-64 \%$ in PCA cases and was shown as the cause of the disease, while some authors argued that sun expoosure was not effective. ${ }^{[13,17,26,28,30]}$ In this study, a patient with PCA had a history of severe sunburn.

Almost any type of inflammation and trauma applied to the skin can cause PIH. Also, ultraviolet radiation facilitates pigmentation. ${ }^{[5-8,14]}$ Pigmentation may worsen with repeated ultraviolet. In our study, only one patient (7.6\%) with PIH had a history of severe sunburn, while the others did not have a history of ultraviolet exposure. This may indicate that ultraviolet may be effective in $\mathrm{PIH}$ etiology.

Certain dermatoses can cause $\mathrm{PIH}$ without indicating inflammation. ${ }^{[7]}$ In this study, the rate of itching in these patients was $53.8 \%$. Although they did not give a history of inflammatory dermatosis in this group of patients, the presence of itching suggests the possibility of an inflammatory event.

Cheng et al. ${ }^{\left[{ }^{[0]}\right.}$ did not found drug intake in cases with EDP. It was observed in our cases that there was a history of drug intake related to their accompanying diseases. However, it was not understood which drugs could be effective.
There may be familial predisposition in cases with amyloidosis. In various studies, this rate was found to be between $2.9-33 \%{ }^{[13,21-23,26,29,34]}$ We did not find family history in our patients.

$\mathrm{PIH}$ is more common in dark skinned races such as Malaysia and India. ${ }^{[2,7]}$ This can be explained by the genetic predisposition and skin type facilitating the formation of pigmentation.

We detected drug-induced pigmentation in only one case. However, what the drug was, could not be found in the records. Detailed drug, herbal or food supplement, chemical exposure should be questioned in patients presenting with hyperpigmentation. ${ }^{[12,32]}$

In general, half of our patients had an accompanying disease. Thyroid pathology was detected on six patients, iron deficiency anemia, hypertension, asthma were detected on four patients, diabetes mellitus,vit BI 2 deficiency anemia were detected on three patients, fibromyalgia and vit $D$ deficiency were detected on two patients, varicose veins, migraine, depression, and allergic rhinitis were detected on one patient. Concomitant skin diseases such as psoriasis, vitiligo, chronic urticaria, atopic dermatitis, perforating collagenesis were also detected. The rate of having more than one disease was $31.8 \%$ ( 14 cases). It may be that the accompanying diseases are itchy or trigger itching, making hyperpigmentation easier. In addition, some authors argue that diseases such as vit BI2 deficiency and thyroid disease can lead to hyperpigmentation. ${ }^{[20]}$ In this study, vit $\mathrm{BI} 2$ and thyroid pathology were found to accompany in a few cases.

Amyloidosis can be associated with various systemic diseases and dermatoses. In studies investigating amyloidosis, accompanying diseases were found at different rates such as $1.47-57 \% .{ }^{[21,23,24,38]}$ In some studies, diabetes mellitus was found at a rate of $8-57 \%$ and the authors suggested that amyloidosis may be related to diabetes. ${ }^{[21,23,26,29]}$ In this study, the presence of diabetes was not detected in amyloidosis cases. However, diabetes mellitus was detected in 3 cases including PIH and EDP. In some studies, $36 \%$ hypertension (HT) association was found in cases with amyloidosis. ${ }^{[6,29]}$ We did not find HT in this group of patients, but we were found in patients with PIH. Photosensitive effects of antihypertensive drugs used by the patients may also cause hyperpigmentation.

Jayabhanu et al. ${ }^{[29]}$ found $14.7 \%$ asthma and $1.4 \%$ thyroid disease in cases with amyloidosis. In this study, 9\% $(n=2)$ thyroid disease and $13.6 \%(n=3)$ asthma were found in cases with amyloidosis.

Mehrotra et al. ${ }^{[23]}$ detected psoriasis in only one case like us. Bandlish et al. ${ }^{[26]}$ found diseases such as urticaria, acne, xerosis, and hirsutism as accompanying diseases in their amyloidosis studies.

All diseases in this study can be differentially diagnosed with each other. A good history, clinical examination, and histopathological examination are required to differentiate them. Detection of amyloid accumulation in histopatho- 
logical evaluation is important for the diagnosis of amyloidosis. ${ }^{[9,15]}$

Macular amyloidosis is often confused with post-inflammatory hyperpigmentation. Lichen simplex chronicus, notalgia paresthetica, poikiloderma, diffuse hyperpigmentation, erythema dyschromicum perstans, phototoxic contact dermatitis, drug-induced pigmentation are other diseases that should be considered.

Lichen amyloidosis is differentially diagnosed with diseases such as lichen simplex chronicus, lichen planus, lichen hypertrophicus, prurigo nodularis, and papular mucinosis. ${ }^{[1,2]}$

In some studies conducted in our country, investigators detected $12.5-50 \%$ of macular amyloid in the biopsies of patients with clinically suspected PIH and stated that histopathological examination should be performed in cases with hyperpigmentation. ${ }^{[39,40,41]}$ In this study, history, separative diagnosis is applied on all our patients. History, clinical findings and histopathology were evaluated together, and $51 \%$ of amyloid was found. Therefore, histopathology is necessary for correct diagnosis and treatment and will guide us. There was no dermatosis, drug history or systemic disease to explain the hyperpigmentation in the cases ofnegative amyloid.

Hyperpigmentation is difficult to treat. If a cause can be detected, priority should be on that cause. There are treatment options according to the type of disease. ${ }^{[2,3]}$

Until now, none of the methods used in the treatment of macular and lichen amylodosis have been fully successful. Treatment is usually symptomatic and does not remove amyloid deposits. ${ }^{[2,3]}$

In the treatment of macular and lichen amyloidosis, potent topical corticosteroids, topical capseicin, topical immunomodulators such as tacrolimus, topical dimethyl sulfoxide (DMSO), hydrocolloid covers, systemic retinoids, colchicine, amitriptyline, low dose cyclophosphamide, cyclosporine, $\mathrm{CO}_{2}$ laser therapy, phototherapy, TENS, cryotherapy can be used. ${ }^{[4]}$ In our study, it was found that the treatments of narrowband UVB and isotretinoin were applied to the patients with macular amyloidosis, and isotretinoin was applied to the patients with lichenoid amyloidosis as treatment options.

Various topical pigmenting agents such as hydroquinone, tretinoin, kojic acid, azeleic acid, ascorbic acid, niacinamide, chemical peeling and various laser and light treatments can be tried in the treatment of $\mathrm{PIH} .{ }^{[8,9,15,33]}$ In this study, it was observed that Kligman formula including topical retinoic acid, steroid and hydroquinone was applied to patients with $\mathrm{PIH}$. Although the treatment results were good, it was stated that hyperpigmentation tended to recur after a while after the interruption of the treatment.

Studies on EDP treatment are few. Agents such as hydroquinone, topical steroid, tacrolimus, retinoids, clofazimine, and narrowband $B$ therapy can be used in the treatment. $[9,10]$ In the treatment of EDP, oral isotretinoin, narrowband $B$ treatment and depigmenting agents were observed in this study. While some of the cases benefited, it was found that some did not.

Various treatments such as amitriptyline, pregabalin, tacrolimus, TENS (transcutaneous electrical nerve stimulation) are used in the treatment of patients with NP in the literature. ${ }^{[11,36]}$ In this study, it was found that low dose Pregabalin was given to one patient and the patient benefited from the treatment.

Ethics Committee Approval

The Ethics Committee was not applied because it was a retrospective study.

Informed Consent

Retrospective study.

Peer-review

Internally peer-reviewed.

Authorship Contributions

Concept: A.A.; Design: A.A.; Supervision: A.A., F.K.; Fundings: None; Materials: A.A., F.K.; Data: A.A., F.K.; Analysis: A.A., F.K.; Literature search: A.A.; Writing: A.A.; Critical revision: A.A., F.K.

Conflict of Interest

There are not any conflicts of interests between the authors.

\section{REFERENCES}

1. Gerçeker Türk B, Öztürk G. Kutanöz amiloidozis. Turkiye Klinikleri J Immunol Rheumatol-Special Topics 2008;1:46-5.

2. Graves RW: Metabolic and systemic diseases: amyloidosis. In: Bolognia J, Schaffer J, Cerroni L, editors. Dermatology Textbook vol 1. 4th edition. China: Elsevier; 2018. p. 754-63.

3. Fernandez-Flores A. Cutaneous amyloidosis: a concept review. Am J Dermatopathol 2012;34:1-17.[CrossRef]

4. Weidner T, Illing T, Elsner P. Primary Localized Cutaneous Amyloidosis: A Systematic Treatment Review. Am J Clin Dermatol 2017;18:629-42.[CrossRef]

5. Lamel SA, Rahvar M, Maibach HI. Postinflammatory hyperpigmentation secondary to external insult: an overview of the quantitative analysis of pigmentation. Cutan Ocul Toxicol 2013;32:67-71.[CrossRef]

6. Kaufman BP, Aman T, Alexis AF. Postinflammatory Hyperpigmentation: Epidemiology, Clinical Presentation, Pathogenesis and Treatment. Am J Clin Dermatol 2018;19:489-503. [CrossRef]

7. Davis EC, Callender VD. Postinflammatory hyperpigmentation: a review of the epidemiology, clinical features, and treatment options in skin of color. J Clin Aesthet Dermatol 2010;3:20-31.

8. Callender VD, St Surin-Lord S, Davis EC, Maclin M. Postinflammatory hyperpigmentation: etiologic and therapeutic considerations. Am J Clin Dermatol 2011;12:87-99. [CrossRef]

9. Cestari TF, Dantas LP, Boza JC. Acquired hyperpigmentations. An Bras Dermatol 2014;89:11-25. [CrossRef]

10. Cheng HM, Chuah SY, Gan EY, Jhingan A, Thng STG. A retrospective clinico-pathological study comparing lichen planus pigmentosus with ashy dermatosis. Australas J Dermatol 2018;59:322-7. [CrossRef]

11. Howard M, Sahhar L, Andrews F, Bergman R, Gin D. Notalgia paresthetica: a review for dermatologists. Int J Dermatol 2018;57:388-92

12. Durmaz E. Drug-Induced Pigmentation. Türkiye Klinikleri J Derma- 
tol Special Topics 2015;847-5.

13. Ollague W, Ollague J, Ferretti H. Epidemiology of primary cutaneous amyloidoses in South America. Clin Dermatol 1990;8:25-9. [CrossRef]

14. Silpa-Archa N, Kohli I, Chaowattanapanit S, Lim HW, Hamzavi I. Postinflammatory hyperpigmentation: A comprehensive overview: Epidemiology, pathogenesis, clinical presentation, and noninvasive assessment technique.J Am Acad Dermatol 2017;77:591-605. [CrossRef]

15. Chang MW. Disorders of hyperpigmentation. In: Bolognia J, Schaffer J, Cerroni L, editors. Dermatology. 4th ed. China: Elsevier Saunders; 2018. p. 1115-43.

16. Lapeere H, Boone B, Schepper SD, Verhaeghe E, Gele MV, Ongenae $\mathrm{K}$ et al. Hypomelanoses and hypermelanoses. In: Wolff K, Goldsmith LA, Katz SI, Gilshrest BA, Paller AS, Leffell DJ, editors. Fitzpatrick's dermatology in general medicine. 8th ed. New York: McGraw Hill Companies Inc; 2012. p. 804-26.

17. Eswaramoorthy V, Kaur I, Das A, Kumar B. Macular amyloidosis: etiological factors. J Dermatol 1999;26:305-10. [CrossRef]

18. Elçin Z. Sırtta hiperpigmentasyonla başvuran hastalarda kutanöz amiloidoz ve atopinin araştırılması. [Tipta Uzmanlık Tezi]. İstanbul: SBÜ Haydarpaşa Numune Eğitim ve Araştırma Hastanesi, Deri ve Zührevi Hastalıklar Kliniği; 2005.

19. al-Ratrout JT, Satti MB. Primary localized cutaneous amyloidosis: a clinicopathologic study from Saudi Arabia. Int J Dermatol 1997;36:428-34. [CrossRef]

20. Chandran V, Kumarasinghe SP. Macular pigmentation of uncertain aetiology revisited: two case reports and a proposed algorithm for clinical classification. Australas J Dermatol 2017;58:45-9. [CrossRef]

21. Salim T, Shenoi SD, Balachandran C, Mehta VR. Lichen amyloidosus: a study of clinical, histopathologic and immunofluorescence findings in 30 cases. Indian J Dermatol Venereol Leprol 2005;71:166-9.

22. Wang WJ, Chang YT, Huang CY, Lee DD. Clinical and histopathological characteristics of primary cutaneous amyloidosis in 794 Chinese patients. Zhonghua Yi Xue Za Zhi (Taipei) 2001;64:101-7.

23. Mehrotra K, Dewan R, Kumar JV, Dewan A. Primary Cutaneous Amyloidosis: A Clinical, Histopathological and Immunofluorescence Study. J Clin Diagn Res 2017;11:WC01-5. [CrossRef]

24. Kilaparty K, Maripati L. Clinicoepidemiological and histopathological study of cutaneous amyloidosis with histopathological correlation. Int J Adv Med 2016;3:731-6. [CrossRef]

25. Kibbi AG, Rubeiz NG, Zaynoun ST, Kurban AK. Primary localized cutaneous amyloidosis. Int J Dermatol 1992;31:95-8. [CrossRef]

26. Bandhlish A, Aggarwal A, Koranne RV. A clinico-epidemiological study of macular amyloidosis from north India. Indian J Dermatol
2012;57:269-74. [CrossRef]

27. Jairajpuri Z, Rana S, Khetrapal S, Arora P, Jetley S. Cutaneous Amyloidosis: A Pilot Study at a Teaching Hospital in New Delhi. J Medicine 2018;19:35-9. [CrossRef]

28. Taheri R. Prevalence of macular amyloidosis in North Iran. Indian Journal of Dermatology 2007;52:192-3. [CrossRef]

29. Jayabhanu AA, Bubna AK, Rangarajan S, Veeraraghavan M, Joseph LD, Sundaram M. A clinicopathologic study of cutaneous amyloidosis at a tertiary health care center in South India. Pigment Int 2016;3:17-23. [CrossRef]

30. Rasi A, Khatami A, Javaheri SM. Macular amyloidosis: an assessment of prevalence, sex, and age. Int J Dermatol 2004;43:898-9. [CrossRef]

31. Ozkaya-Bayazit E, Kavak A, Güngör H, Ozarmagan G. Intermittent use of topical dimethyl sulfoxide in macular and papular amyloidosis. Int J Dermatol 1998;37:949-54. [CrossRef]

32. Güven M, Eren Bozdağ K. Diagnostic Approach to Hyperpigmentation Disorders. Eren Bozdağ K, editör. Pigmentasyon. Ankara: Türkiye Klinikleri;2018. p.1-9.

33. Chang SE, Kim HW, Shin JM, Lee JH, Na JI, Roh MR, et al. Clinical and histological aspect of erythema dyschromicum perstans in Korea: A review of 68 cases. J Dermatol 2015;42:1053-7. [CrossRef]

34. Krishna A, Nath B, Dhir GG, Kumari R, Budhiraja V, Singh K. Study on epidemiology of cutaneous amyloidosis in northern India and effectiveness of dimethylsulphoxide in cutaneous amyloidosis. Indian Dermatol Online J 2012;3:182-6. [CrossRef]

35. Wong CK. Lichen amyloidosus. A relatively common skin disorder in Taiwan. Arch Dermatol 1974;110:438-40. [CrossRef]

36. Savk E, Savk O, Bolukbasi O, Culhaci N, Dikicioğlu E, Karaman G, et al. Notalgia paresthetica: a study on pathogenesis. Int J Dermatol 2000;39:754-9. [CrossRef]

37. Yoshida A, Takahashi K, Tagami H, Akasaka T. Lichen amyloidosis induced on the upper back by long-term friction with a nylon towel. $\mathrm{J}$ Dermatol 2009;36:56-9. [CrossRef]

38. Looi LM. Primary localised cutaneous amyloidosis in Malaysians. Australas J Dermatol 1991;32:39-44. [CrossRef]

39. Tufan H, Ergenekon G, Başak T, Tirpancı A, Aybey B, Yıldız H. Macular amyloidosis. Turkiye Klinikleri J Dermatol 1997;7:23-6.

40. Acar A, Özpoyraz M. Sırt bölgesindeki hiperpigmente maküllerde amiloidoz. Deri Hast Frengi Arş 1989;23:167-73.

41. Akyol M, Pout M, Özçelik S, Elagöz Ş, Marufihah M. The Histopathologic Investigation of Macular Amyloidosis in the Cases Who Had Diagnosed Postinflammatory Hyperpigmentationin Clinic. C Ü Tip Fakültesi Dergisi 2001;23:43-5. 


\section{Yaygın Hiperpigmentasyonla Başvuran Hastaların Klinik ve Demografik Özellikleri}

Amaç: Hiperpigmentasyon epidermis ve dermiste pigment birikmesiyle karakterize bir durumdur. Primer kutanöz amiloidoz (PKA), postinflamatuvar hiperpigmentasyon (PiH), eritema diskromikum perstans (EDP), notaljia parestetika (NP), ilaç reaksiyonu (IR) gibi bir çok dermatolojik hastalık vücutta kazanılmış hiperpigmentasyona neden olabilmektedir. Bu çalışmada; yaygın hiperpigmentasyonla başvuran hastalarda etyolojik nedenler, hastaların demografik özellikleri, klinik ve laboratuvar bulguları, tedavi seçeneklerinin literatür bilgileri ile karşılaştırarak sunulması amaçlandı.

Gereç ve Yöntem: Polikliniğimize yaygın hiperpigmentasyon şikayeti ile başvuran 44 hasta retrospektif olarak değerlendirildi. Hastalar; yaş, lezyon süresi, lokalizasyonu, eşlik eden semptom ya da hastalıklar, laboratuvar bulguları ve tedavi seçenekleri açısından gözden geçirildi.

Bulgular: Pigmentasyona neden olan hastalıklar sıralandığında; olguların \%50' sinde PKA tespit edildi. Bunun \%72.7’ si ( $n=16)$ maküler amiloidoz, \%22.7' si $(n=5)$ liken amiloidoz, \%4.6'ü $(n=1)$ bifazik amiloidoz idi. Diğerleri \%29.5 $(n=13)$ PiH, \%।3.6 $(n=6)$ EDP, \%4.6 ( $n=2)$ NP, \%2.3 $(n=I)$ İR olarak saptandı. Hastaların yaşları genel olarak 20-69 yaş (ortalama 47.8) arasında ve kadınlarda 48.8, erkeklerde 45.0 olarak bulundu. Hastaların \%75' i kadındı. Pigmentasyon süresi 3ay ile 20 yıl (ort 6.8 yıl) arasında değişiyordu. Hastaların \%75 (n=33)' inde kaşıntı yakınması mevcuttu. Lezyonların yaklaşık yarısı sırtta yerleşmişti. Hastaların yarısında eşlik eden bir hastalık vardı. Tedavi seçenekleri olarak hastaların 9' una fototerapi, 9' una isotretinoin, I2' sine depigmentasyon tedavisi, birer olguya pregabalin ve topikal steroid verilmişti.

Sonuç: Hiperpigmentasyona neden olan durumların iyi bilinmesi hastalığın tanısını kolaylaştıırı. Bu çalışmada klinik olarak hiperpigmentasyon düşünülen hastaların yarısında PKA tespit edilmiştir. Bu nedenle kaşıntılı ve yaygın pigmentasyonla gelen hastalarda PKA tanısı öncelikle düşünülmelidir. PiH olguları da azımsanmayacak kadar fazladır. Bu konuda ayrıntılı prospektif çalışmalara ihtiyaç vardır.

Anahtar Sözcükler: Amiloidoz; epidemiyoloji; eritema diskromikum perstans; pigmentasyon. 